\title{
RANCANG BANGUN APLIKASI UJIAN ONLINE STUDI KASUS: SMK 1 PGRI CIKAMPEK
}

\author{
Dede Firmansyah Saefudin ${ }^{1}$, Yuli komalasari ${ }^{2}$, Evi maesyari ${ }^{3}$ \\ ${ }^{1}$ Teknik \& Informatika, Universitas Bina sarana Informatika PSDKU Karawang, Jalan Banten No.1 \\ Karangpawitan Karawang \\ email: dede.dfs@bsi.ac.id \\ ${ }^{2}$ Teknik \& Informatika, Universitas Bina sarana Informatika Jalan Kamal Raya No.18, ringroad \\ Barat,Cengkareng Jakarta barat, 11710, Indonesia \\ Email: yuli.yks@bsi.ac.id \\ ${ }^{3}$ Teknik \& Informatika, Universitas Bina sarana Informatika PSDKU Karawang, Jalan Banten No.1 \\ Karangpawitan Karawang
}

\begin{abstract}
Abstrak
Revolusi industri 4.0 telah mulai memasuki jamannya, yang menekankan pola ekonomi digital, kecerdasan buatan, data besar, robot, atau dikenal sebagai fenomena inovasi yang mengganggu. Education 4.0 adalah fenomena yang merespon kebutuhan akan munculnya revolusi industri 4.0 di mana manusia dan mesin disejajarkan untuk mendapatkan solusi, menyelesaikan masalah dan tentu saja menemukan kemungkinan baru inovasi. Era Pendidikan 4.0 sangat berpengaruh bagi dunia pendidikan, karena juga mengalami peningkatan kualitas, kecepatan dan kepraktisan. Ujian online dapat dikatakan milik era Pendidikan 4.0 karena ujian konvensional (manual) telah bergeser ke arah komputerisasi. Tes online (Tes Online) adalah salah satu metode untuk mengevaluasi hasil belajar atau mengukur tingkat kemampuan seseorang menggunakan komputer. Oleh karena itu, penulis meneliti sistem ujian online berbasis web di SMK PGRI Cikampek. Saat ini sistem ujian tengah semester (UTS) dan ujian kelulusan (UKK) yang diterapkan di sekolah masih konvensional (manual). Sehingga guru sering mengalami kendala teknis dalam memproses soal dan hasil ujian, seperti lembar jawaban yang rusak, pembagian soal yang tidak merata, kebocoran soal yang ditimbulkan saat pembagian, dan sebagainya. Rancang bangun aplikasi ujian online berbasis website menggunakan model Waterfall dengan melalui tahapan Analisa, Desain, Pengkodean dan pengujian unit dan penggunaan diagram UML (Unified Modelling Language) untuk menggambarkan rancangan sistem usulan, sedangkan untuk media penyimpanan data menggunakan Mysql Database. Diharapkan dapat dapat mengurangi atau bahkan meminimalkan masalah yang terjadi dalam pelaksanaan ujian konvensional (manual) karena dengan sistem komputerisasi semuanya dapat dikelola dan dipantau lebih rapi dengan mudah dan terpusat.
\end{abstract}

Kata kunci: aplikasi, ujian, online

\begin{abstract}
The industrial revolution 4.0 has begun to enter its era, which emphasizes the pattern of the digital economy, artificial intelligence, big data, robots, or what is known as a disturbing phenomenon of innovation. Education 4.0 is a phenomenon that responds to the need for the emergence of the industrial 4.0 revolution where humans and machines are aligned to get solutions, solve problems, and of course discover new possibilities for innovation. Education Era 4.0 is very influential for the world of education, because it also experiences an increase in quality, speed, and practicality. Online exams can be said to belong to the era of Education 4.0 because conventional (manual) exams have shifted towards computerization. Online test (Online Test) is one method to evaluate learning outcomes or measure the level of ability of someone using a computer. Therefore, the authors examine the web-based online exam system at SMK PGRI Cikampek. Currently the midterm (UTS) and graduation exam (UKK) systems applied in schools are still conventional (manual). So that teachers often experience technical obstacles in processing questions and exam results, such as broken answer sheets, uneven distribution of questions, leakage of questions caused during distribution, and so on. The design of the website-based online exam application uses the Waterfall
\end{abstract}


model through the stages of Analysis, Design, Coding and unit testing and the use of UML (Unified Modeling Language) diagrams to illustrate the proposed system design, while for data storage media using the Mysql Database. It is expected to reduce or even minimize the problems that occur in the implementation of conventional exams (manual) because with a computerized system everything can be managed and monitored more neatly easily and centrally.

Keywords: application, exam, online, website

\section{PENDAHULUAN}

Pendidikan 4.0 adalah situasi atas respon kebutuhan karena revolusi industri 4.0 sebagai penyelarasan untuk suatu solusi antara manusia dengan mesin, munculnya inovasi baru adalah suatu representasi dari situasi tersebut. Era Pendidikan 4.0 berpengaruh terhadap sektor pendidikan, kemudahan akses dan pengurangan penggunaan terhadap kertas menjadikan suatu solusi yang tepat bagi dunia pendidikan saat ini.

Ujian online (Online Test) merupakan salah satu metode penilaian hasil pembelajaran atau mengukur tingkat kemampuan seseorang menggunakan computer[1]. Saat ini pun Pemerintah mewajibkan Ujian Nasional Berbasis Komputer (UNBK) bagi sekolah tingkat SLTA (SMA/SMK/MA). Bukan hanya itu, Ujian sekolah yang distandarkan secara nasional atau dikenal sebagai USBN pun sudah sebagian sekolah menggunakan Computer Based Test (CBT) atau ujian berbasis komputer. Pelaksanaan ujian dengan sistem CBT atau Computer Based Test tentu memiliki perbedaan dengan sistem PBT atau Paper Based Test dalam hal media pengerjaan. Peserta ujian menggunakan sistem CBT langgung dapat memilih jawaban yang benar pada layar komputer. Pada sistem CBT peserta ujian hanya perlu menggeser dan klik kursor pada jawaban yang dianggap benar, sedangkan sistem PBT peserta diwajibkan menghitamkan bulatan di kertas lembar jawaban. SMK PGRI Cikampek adalah sekolah kejuruan swasta yang cukup terkenal dikota Cikampek. Saat ini sistem Ujian Tengah Semester (UTS) dan Ujian Kenaikan Kelas (UKK) yang dilaksanakan di sekolah tersebut masih bersifat konvensional (manual). Sehingga para guru seringkali mengalami kendala teknis dalam pengolahan soal-soal dan hasil ujian, seperti tentang lembar jawaban yang rusak, pembagian soal yang tidak merata, kebocoran soal yang disebabkan saat distribusi, dan sebagainya.

Sekarang ini belum banyak sekolah di Indonesia terutama di kota Cikampek menyelenggarakan UTS dan UKK secara online. Dengan ujian online sekolah dapat mengurangi bahkan meminimalisir masalah-masalah yang terjadi pada pelaksanaan ujian konvensional (manual) karena dengan sistem komputer semua dapat dikelola dan dipantau lebih rapih secara mudah dan terpusat. Hanya dengan password dan kartu ujian siswa sudah dapat mengikuti ujian. Atas dasar identifikasi masalah yang telah dipaparkan diatas, maka rumusan masalah pada penelitian ini adalah bagaimana jika sistem ujian konvensional (manual) diganti dengan sistem ujian online untuk pelaksanaan ujian. Dengan demikian, tidak akan ada lagi pihak-pihak yang mengalami kendala dalam pelaksanaan ujian, sehingga ujian akan menjadi lebih efektif dan efisien baik dari segi waktu, tempat, biaya, media dan tenaga. 


\section{TINJAUAN PUSTAKA}

\subsection{Sistem Informasi}

Sistem informasi adalah suatu sistem didalam organisasi yang mempertemukan kebutuhan pengolahan transaksi harian, mendukung operasi, bersifat manajerial, dan kegiatan strategi dari suatu organisasi dan menyediakan pihak luar tertentu dengan laporanlaporan yang dibutuhkan[2]. Membangun suatu sistem informasi memerlukan pemahaman yang baik dan jelas mengenai sistem yang akan digunakan baik dalam prosedur sistem, input, output maupun hal-hal yang mempengaruhi kinerja sistem baik untuk jangka pendek maupun jangka panjang[3].

\subsubsection{Ujian Online}

Ujian online pada dasarnya sama seperti ujian konvensional yang sudah di terapkan di dunia pendidikan, seperti sekolah atau lembaga kursus. Tahapan ujian dilakukan mulai guru membuat soal, lalu membuat jawaban, serta kunci jawabannya, setelah itu guru membagikan soal tersebut ke siswa sesuai dengan jadwal ujian dan kelas yang telah ditentukan sebelumnya. Namun yang membedakan antara ujian konvensional dan ujian online adalah media yang digunakan dan aturan-aturan pelaksanaan ujian[4].

\subsection{Penelitian Terdahulu}

Berdasarkan penelitian dalam jurnal yang berjudul "Rancang Bangun Sistem Informasi Ujian Online Berbasis Web Menggunakan Metode Waterfall" menyimpulkan bahwa : Pembuatan sistem ujian online merupakan sarana ujian yang bersifat online untuk mengoptimalkan kegiatan ujian. Sistem Ujian online memberikan manfaat yaitu tidak perlu melakukan pengadaan kertas ujian dan menghemat waktu untuk koreksi ujian. Fungsi random soal pada sistem ujian online dapat mengurangi kecurangan-kecurangan yang dilakukan peserta ujian karena soal yang disajikan bervariasi sehingga peserta ujian akan menerima soal yang berbeda-beda antara satu dengan yang lain[5].

Berdasarkan penelitian dalam jurnal yang berjudul "Sistem Informasi Ujian Mandiri Online Berbasis Web Di Smpn 1 Srandakan" menyimpulkan bahwa : Penelitian ini menghasilkan sistem informasi ujian mandiri online berbasis web yang dapat digunakan untuk menguji kemampuan siswa dalam menyerap pelajaran disekolah. Sistem ini mampu memberikan nilai secara langsung tanpa harus mengoreksi lembar jawaban siswa satu persatu sehingga mempercepat dalam proses penilaian ujian siswa dan menimalisirkan terjadinya human error[1].

Berdasarkan penelitian dalam jurnal yang berjudul "Sistem Ujian Online Berbasis Website" menyimpulkan bahwa : Perangkat lunak ujian online yang dibangun dalam penelitian ini membutuhkan aplikasi web server dan DBMS yang mendukung. Secara fungsional ada 5 prosedur yang terlibat antara lain manajemen peserta, manajemen ujian, manajemen soal ujian, pelaksanaan ujian dan laporan hasil ujian. Setelah melewati tahapan analisis kebutuhan fungsional maka perangkat lunak ujian online tersebut dibangun dengan 7 dialog utama yang terbagi antara dosen dan peserta. Dialog tersebut antara lain adalah manajemen group soal, manajemen soal, manajemen daftar peserta ujian, laporan hasil ujian, login, pengerjaan ujian dan konfirmasi hasil ujian[6].

Berdasarkan penelitian dalam jurnal yang berjudul "Aplikasi Ujian Online Pada Smk Ma'arif Bandung Berbasis Web" menyimpulkan bahwa : Permasalahan pada proses ujian di SMK Ma'arif Bandung baik dari segi waktu dan finansial sudah berjalan lama, sehingga pengeluaran biaya dan waktu juga sudah terbuang banyak. Dengan adanya aplikasi ujian ini, 
proses ujian di SMK Ma'arif Bandung berjalan dengan lancar dan dari segi waktu juga finansial sangatlah murah. Sehingga proses ujian di SMK Ma'arif bandung lebih efektif dan efisien[7].

Berdasarkan penelitian dalam jurnal yang berjudul "Rancang Bangun Sistem Informasi Ujian Online (Studi Kasus Pada Sman 58 Jakarta)" menyimpulkan bahwa : Dengan memakai sistem yang baru dan telah terkomputerisasi maka diharapkan dapat mempermudah dalam proses pelaksanaan dan pengolahan data ujian. Sistem informasi yang dirancang tentunya sesuai dengan kebutuhan user dan dapat digunakan semudah mungkin (user friendly). Penyimpanan dan pengolahan nilai dapat dilakukan lebih mudah, cepat dan efisien dengan tingkat keamanan yang lebih terjamin[8].

\section{METODE PENELITIAN}

\subsection{Metode Pengembangan Perangkat Lunak}

Dalam penelitian yang dilakukan oleh wahyu wijaya widyanto dengan membandingkan 3 model pengembangan perangkat lunak salah satunya adalah model waterfall dengan spesifikasi kelebihan dan kekurangan yang dibuat sebagai berikut:

Tabel 3.1 Spesifikasi model waterfall (Sumber [9])

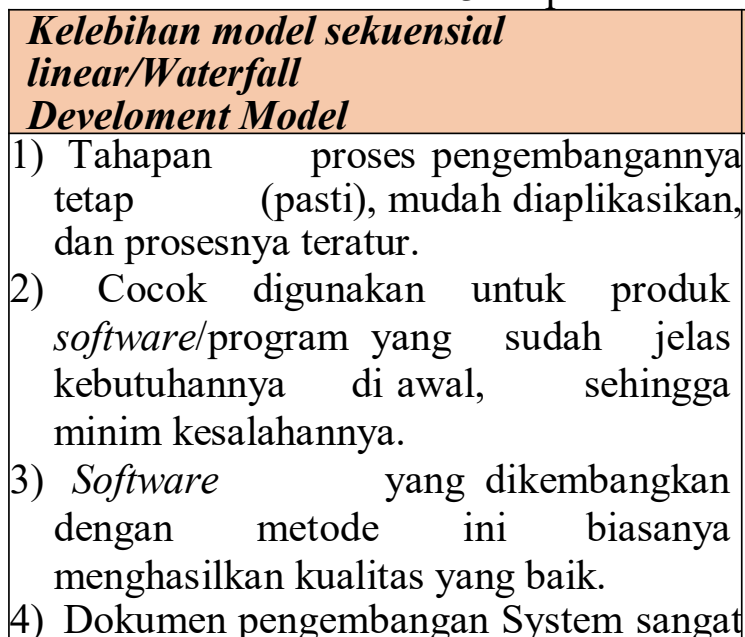
terorganisir, karena setiap fase harus terselesaikan dengan lengkap sebelum melangkah ke fase berikutnya

\section{Kekurangan model sekuensial}

linear/Waterfall

Develoment Model

1) Proyek yang sebenarnya jarang mengikuti alur sekuensial seperti diusulkan, sehingga perubahan yang terjadi dapat menyebabkan hasil yang sudah didapatkan tim pengembang harus diubah kembali/iterasi sering menyebabkan masalah baru.

2) Terjadinya pembagian proyek menjadi tahap- tahap yang tidak fleksibel, karena komitmen harus dilakukan pada tahap awal proses.

3) Sulit untuk mengalami perubahan kebutuhan yang diinginkan oleh customer/pelanggan.

4) Pelanggan harus sabar untuk menanti produk selesai, karena dikerjakan tahap per tahap, dan proses pengerjaanya akan berlanjut ke setiap tahapan bila tahap sebelumnya sudah benar-benar selesai.

5) Perubahan ditengah-tengah pengerjaan produk akan membuat bingung tim pengembang yang sedang membuat produk.

6) Adanya waktu kosong (menganggur) bagi pengembang, karena harus menunggu anggota tim proyek lainnya menuntaskan pekerjaannya 
Dari hasil analisa diatas maka dapat disimpulkan bahwa model waterfall lebih cocok diimplementasikan terhadap sistem informasi yang sudah jelas dari hasil analisa kebutuhan dari awal hingga minim kesalahan karena dilaksanakan secara bertahap, seperti pada penelitian yang dilakukan terkait rancang bangun aplikasi ujian online berbasis website.

Metode yang penulis gunakan untuk pengembangan perangkat lunak ini menggunakan metode waterfall "Model SDLC air terjun (waterfall) sering juga disebut model sekuensial linier (sequential linear) atau alur hidup klasik (classic life cycle). Model air terjun menyediakan pendekatan alur hidup perangkat lunak secara sekuensial atau terurut dimulai dari analisis, desain, pengkodean, pengujian, dan pendukung (support)"[10]. Berikut adalah gambar model air terjun :

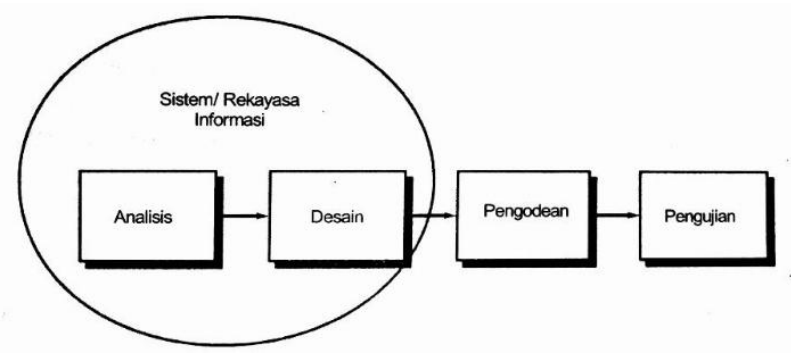

Sumber : (Rosa \& Shalahuddin, 2018)

Gambar I.1: Ilustrasi model waterfall

Model waterfall ini terdiri dari beberapa tahapan dalam sistematika pelaksanaan modelnya. Tahapan waterfall yaitu :

1. Analisis kebutuhan perangkat lunak

Proses pengumpulan kebutuhan dilakukan secara intensif untuk menspesifikasikan kebutuhan perangkat lunak agar dapat dipahami perangkat lunak seperti apa yang dibutuhkan oleh user. Spesifikasi kebutuhan perangkat lunak pada tahap ini perlu untuk didokumentasikan.

2. Desain

Desain perangkat lunak adalah proses multi langkah yang fokus pada desain pembuatan program perangkat lunak termasuk struktur data, arsitektur perangkat lunak, representasi antarmuka, dan prosedur pengodean. Tahap ini mentranslasi kebutuhan perangkat lunak dari tahap analisis kebutuhan ke representasi desain agar dapat diimplementasikan menjadi program pada tahap selanjutnya. Desain perangkat lunak yang dihasilkan pada tahap ini juga perlu didokumentasikan.

3. Pembuatan kode program

Desain harus ditranslasikan ke dalam program perangkat lunak. Hasil dari tahap ini adalah program komputer sesuai dengan desain yang telah dibuat pada tahap desain.

4. Pengujian

Pengujian fokus pada perangkat lunak secara dari segi lojik dan fungsional dan memastikan bahwa semua bagian sudah diuji. Hal ini dilakukan untuk meminimalisir kesalahan (error) dan memastikan keluaran yang dihasilkan sesuai dengan yang diinginkan. 
5. Pendukung (support) atau pemeliharaan (maintenance)

Tidak menutup kemungkinan sebuah perangkat lunak mengalami perubahan ketika sudah dikirimkan ke user. Perubahan bisa terjadi karena adanya kesalahan yang muncul dan tidak terdeteksi saat pengujian atau perangkat lunak harus beradaptasi dengan lingkungan baru. Tahap pendukung atau pemeliharaan dapat mengulangi proses pengembangan mulai dari analisis spesifikasi untuk perubahan perangkat lunak yang sudah ada, tapi tidak untuk membuat perangkat lunak baru.

\subsection{Teknik Pengumpulan Data}

Untuk mendapatkan data-data yang diperlukan, maka penulis menggunakan beberapa metode, yaitu:

1. Observasi (Observation)

Penulis melakukan observasi langsung di SMK PGRI Cikampek untuk melihat bagaimana prosedur pelaksanaan ujian manual dilakukan dan data-data yang terkait dengan penelitian yang dilakukan. Hasil dari pengamatan tersebut adalah sering terjadi kesalahan mengenai pengisian jawaban dengan cara menghitamkan jawaban menggunakan pinsil 2B, sehingga ketika ada kesalahan dan dihapus maka akan mengalami kerusakan pada kertas atau OCR jawaban sehingga berdampak pada pengecekan jawaban, selain itu jadwal yang terkadang berubah dikarenakan hal-hal tertentu sehingga berdampak pada pengumuman kepada siswa yang harus dilakukan berulang kali agar siswa tidak terlambat dalam mengetahui jadwal ujian yang akan dilaksanakan, juga pada peraturan dan tata tertib pengisian ujian yang terkadang masih ada siswa yang terlambat mengumpulkan hasil sehingga berdampak pada keterlambatan waktu pengerjaan.

2. Wawancara (Interview)

Pada penelitian ini, untuk mendapatkan informasi secara lengkap, penulis melakukan tanya jawab atau wawancara dengan Wakil Kepala Sekolah Kurikulum Bapak Irbab Mukhorobin, S,T. mengenai prosedur pelaksaan ujian. Hasil dari wawancara tersebut bahwa ketika sedang berlangsung ujian masih ada siswa yang melakukan kecurangan seperti mencontek teman sebangku, juga dalam pengadaan material seperti kertas dan alat tulis yang seringkali membutuhkan biaya yang tidak sedikit.

\section{Studi Pustaka (Liblary Research)}

Selain melakukan kegiatan diatas penulis juga melakukan studi kepustakaan melalui literatur-literatur atau referensi-referensi yang ada diperpustakaan Universitas Bina Sarana Informatika Karawang dan juga melalui jurnal untuk mempelajari dan memahami penerapan ujian online terkait penelitian yang diambil.

\subsection{Ruang Lingkup}

Didalam penelitian ini, penulis membuat ruang lingkup meliputi proses alur pengolahan data soal sampai terbentuknya sebuah output yaitu sebuah soal ujian, lalu proses pelaksanaan ujian dan proses pengolahan hasil ujian yang akan menghasilkan output hasil nilai ujian murni. Sedangkan ruang lingkup pada perancangan sistem ini terbagi menjadi dua bagian yaitu halaman depan (Front End) meliputi halaman login, halaman siswa yang berisi menu profil siswa, menu jadwal ujian, menu ujian, menu hasil ujian, lalu menu logout. 
Sedangkan halaman administrator (Back End) meliputi menu login, menu manajemen guru, siswa, admin, soal, kelas, mata pelajaran, jadwal ujian, menu hasil ujian, lalu menu logout.

\subsection{Tahapan Perancangan Sistem}

\subsubsection{Analisis Kebutuhan Software}

Analisis kebutuhan merupakan hasil pengembangan dari ruang lingkup masalah sehingga menghasilkan temuan yang secara spesifik dan dapat dibuat dalam bentuk fungsifungsi yang akan diimplementasikan kedalam sistem informasi ujian online berbasis website. Hasil analisa yang dilakukan dapat dibuat sebuah rancangan sistem untuk memenuhi kebutuhan pengguna diantaranya sebagai adminitrator sistem, pengguna dapat mengelola data guru, siswa, kelas, mata pelajaran, jadwal ujian online, melihat hasil ujian, dan mencetak hasil ujian. Sedangkan sebagai pengguna dari sisi siswa, pengguna dapat melihat dan mengupdate profil siswa, melihat jadwal ujian online, melakukan pengerjaan ujian online dan melihat hasil ujian secara online.

\section{HASIL DAN PEMBAHASAN}

\subsection{Rancangan Sistem Usulan}

Dari hasil pengumpulan data melalui metode observasi, wawancara hingga studi pustaka, maka dapat disimpulkan bahwa perlu adanya sistem usulan yang dapat diterapkan yakni dengan dibuatnya suatu sistem ujian online berbasis website. Untuk mendukung perancangan sistem tersebut penulis menggunakan model diagram yakni UML(Unified Modelling Language). Perancangan sistem usulan dalam membangun aplikasi ujian online ini diperlukan untuk memberikan gambaran langkah demi langkah dalam pembuatan sistem informasi atau aplikasi program. Penulis menggunakan beberapa tools perancangan program diantaranya:

1. Usecase Diagram

Use case atau diagram use case merupakan pemodelan untuk kelakukan (behavior) sistem informasi yang akan dibuat. Use case mendeskripsikan sebuah interaksi antara satu atau lebih aktor dengan sistem informasi yang akan dibuat. Secara kasar, use case digunakan untuk mengetahui fungsi apa saja yang ada didalam sebuah sistem informasi dan siapa saja yang berhak menggunakan fungsi-fungsi itu[10]. Dalam diagram use case ujian online bahwa siswa dapat melakukan interaksi terhadap fungsi-fungsi yang ada didalam halaman ujian online. 


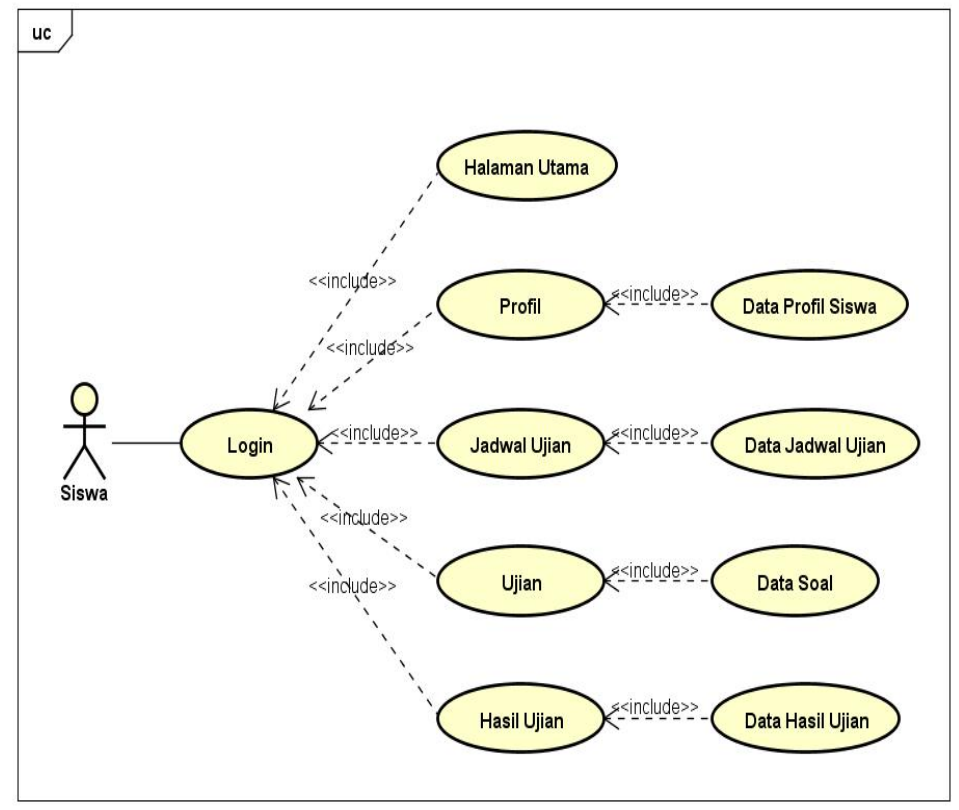

Gambar 3.1: Use Case Diagram Siswa

\section{Activity Diagram}

Diagram aktivitas atau activity diagram menggambarkan workflow (aliran kerja) atau aktivitas dari sebuah sistem atau proses bisnis atau menu yang ada pada perangkat lunak. Yang perlu diperhatikan disini adalah bahwa diagram aktivitas menggambarkan aktivitas sistem bukan apa yang dilakukan aktor, jadi aktivitas yang dapat dilakukan oleh sistem[10].

Berikut ini adalah alur aktifitas sistem dalam bentuk diagram activity pada halaman siswa yang akan mengakses halaman ujian online/daring, dan melakukan ujian online pada halaman ujian tersebut.

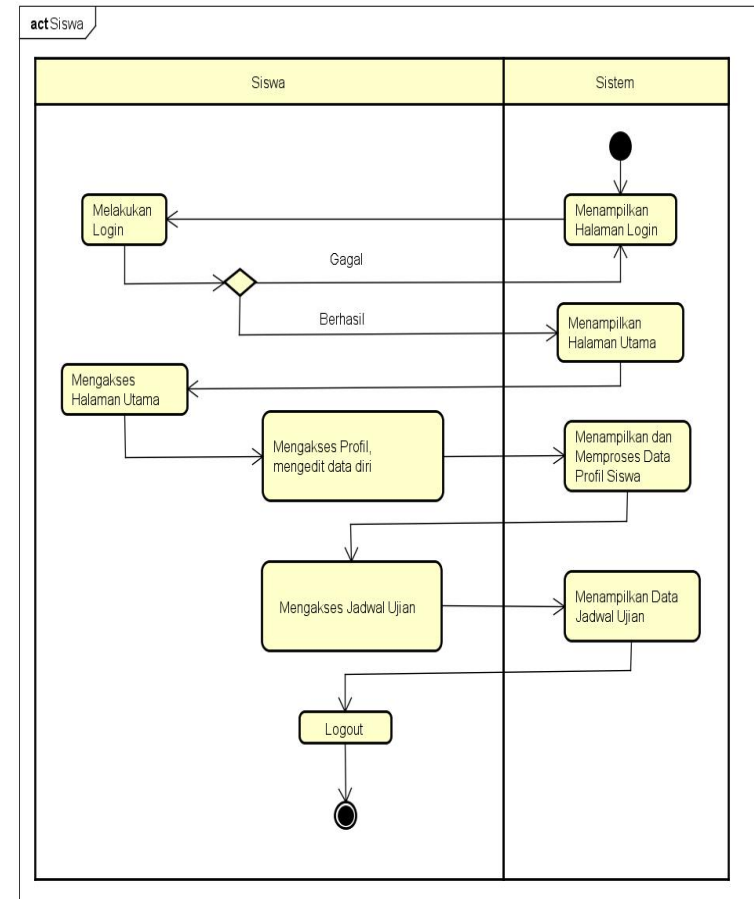

Gambar 3.2: Activity Diagram Siswa 


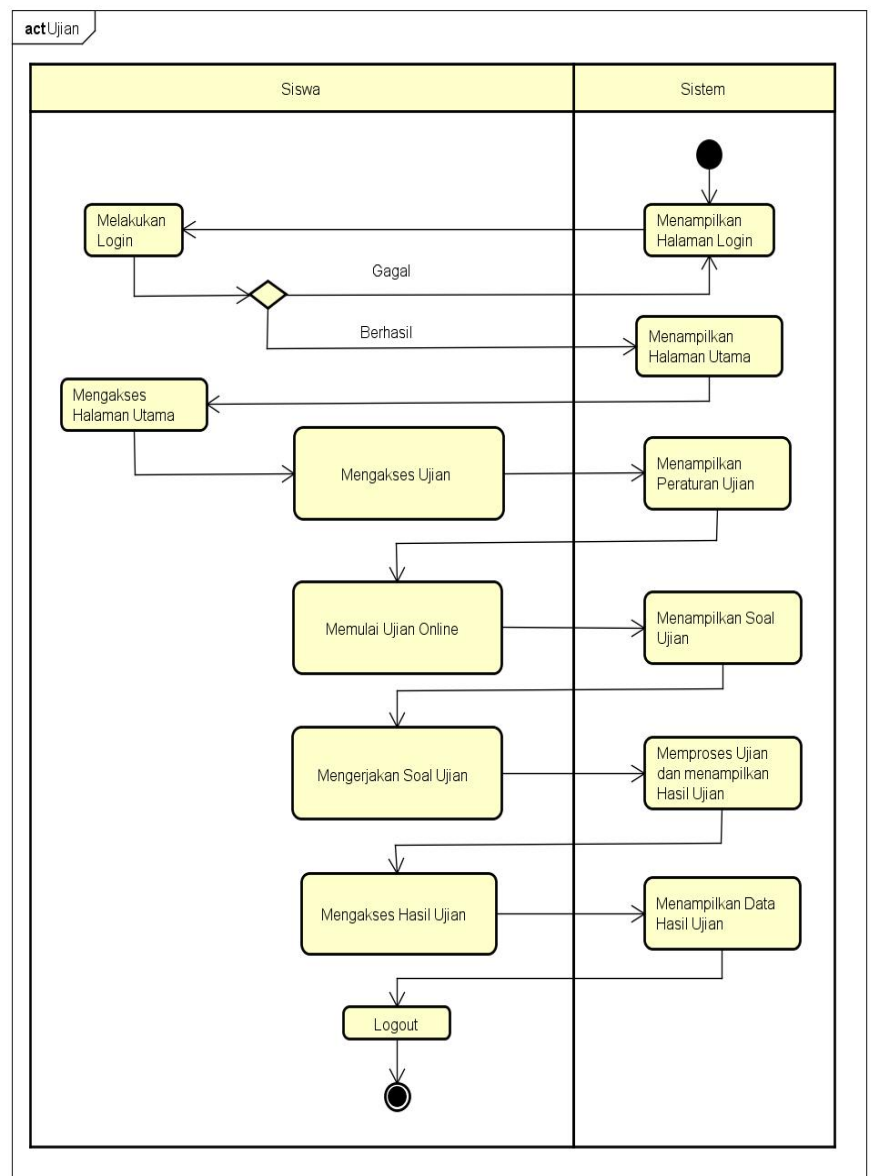

Gambar 3.3: Activity Diagram Ujian

\section{Sequence Diagram}

Diagram sekuen menggambarkan kelakuan objek pada use case dengan mendeskripsikan waktu hidup objek dan message yang dikirimkan dan diterima antar objek. Oleh karena itu untuk menggambarkan diagram sekuen maka harus diketahui objek-objek yang terlibat dalam sebuah use case beserta metode-metode yang dimiliki kelas yang diinstansi menjadi objek itu[10].

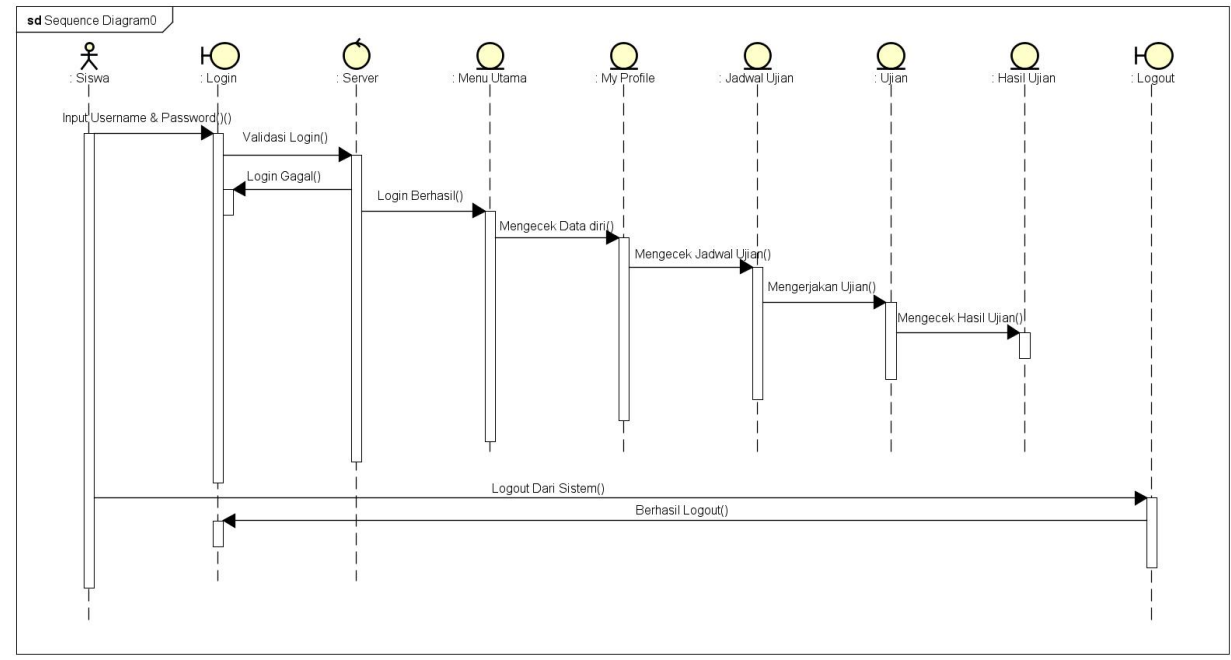

Gambar 3.4: Sequence Diagram Siswa 


\section{Rancangan Database Ujian online}

Entity Relationship Diagram (ERD) adalah suatu rancangan atau bentuk hubungan suatu kegiatan di dalam sistem yang berkaitan langsung dan mempunyai fungsi di dalam proses tersebut. ERD adalah suatu pemodelan dari basis data relasional yang didasarkan atas persepsi di dalam dunia nyata, dunia ini senantiasa terdiri dari sekumpulan objek yang saling berhubungan antara satu dengan yang lainnya[11]. Dalam perancangan database ujian online dibutuhkan beberapa entitas yang memiliki keterkaitan sehingga dapat dilakukan sebuah pengelolaan database yang terdistribusi dengan baik dan aman dari sisi sekuritas.

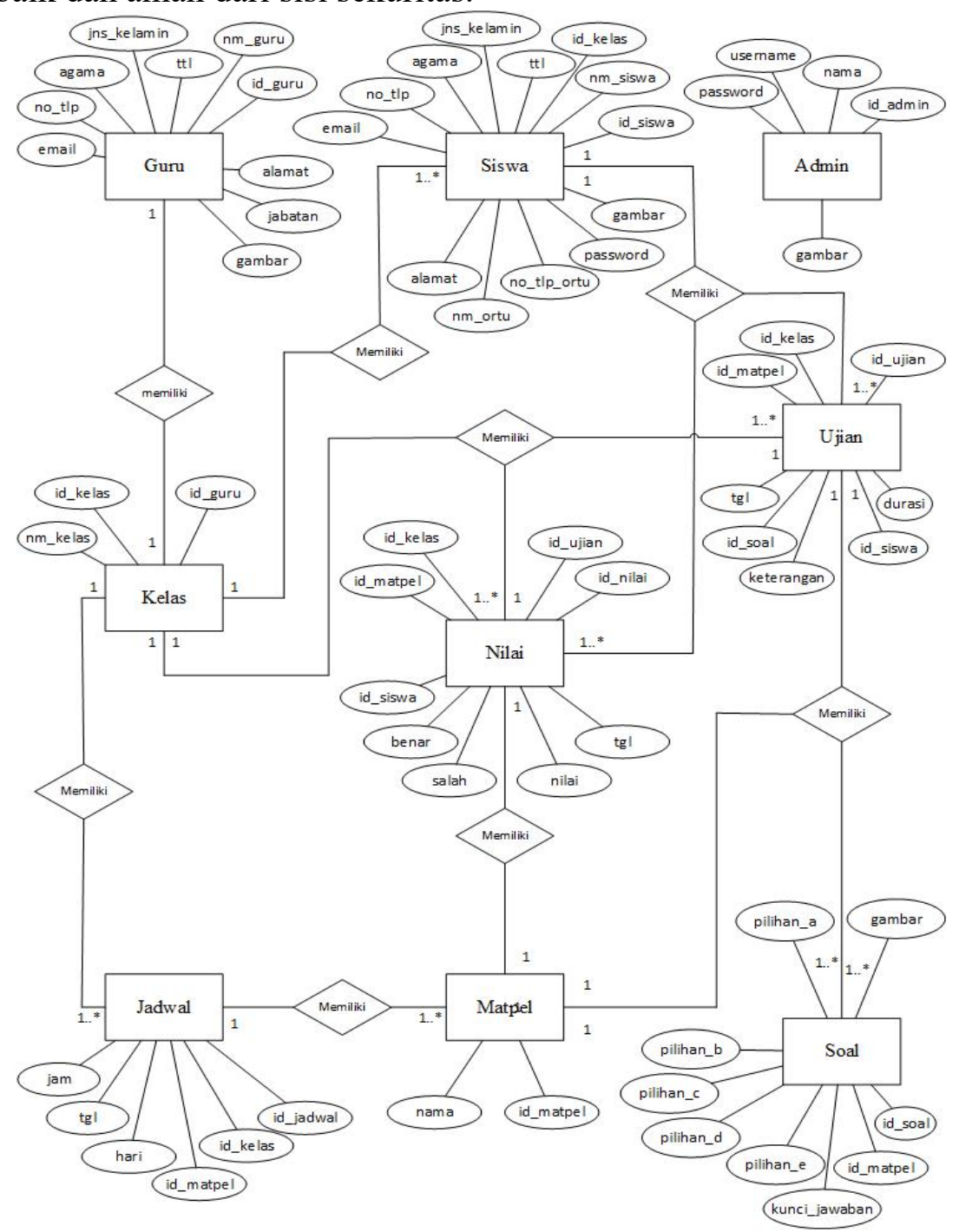

Gambar 3.5: Rancangan Database dalam bentuk ERD

\subsection{HASIL}

\section{A. Implementasi Sistem}

Mengimplementasikan sistem ujian online pada siswa/i dan guru di SMK 1 PGRI cikampek dilakukan untuk mendapatkan evaluasi berikut pengembangan sebuah sistem informasi yang diterapkan. Penerapan rancangan program yang dilakukan sesuai dengan tahapan model pengembangan sistem yang sudah diuraikan. Hasil dari penerapan tersebut adalah berupa sistem informasi ujian online berbasis website yang dapat digunakan 
pengguna berikut adalah tampilan halaman sistem informasi ujian online pada SMK PGRI Cikampek:

\section{Tampilan awal/Beranda}

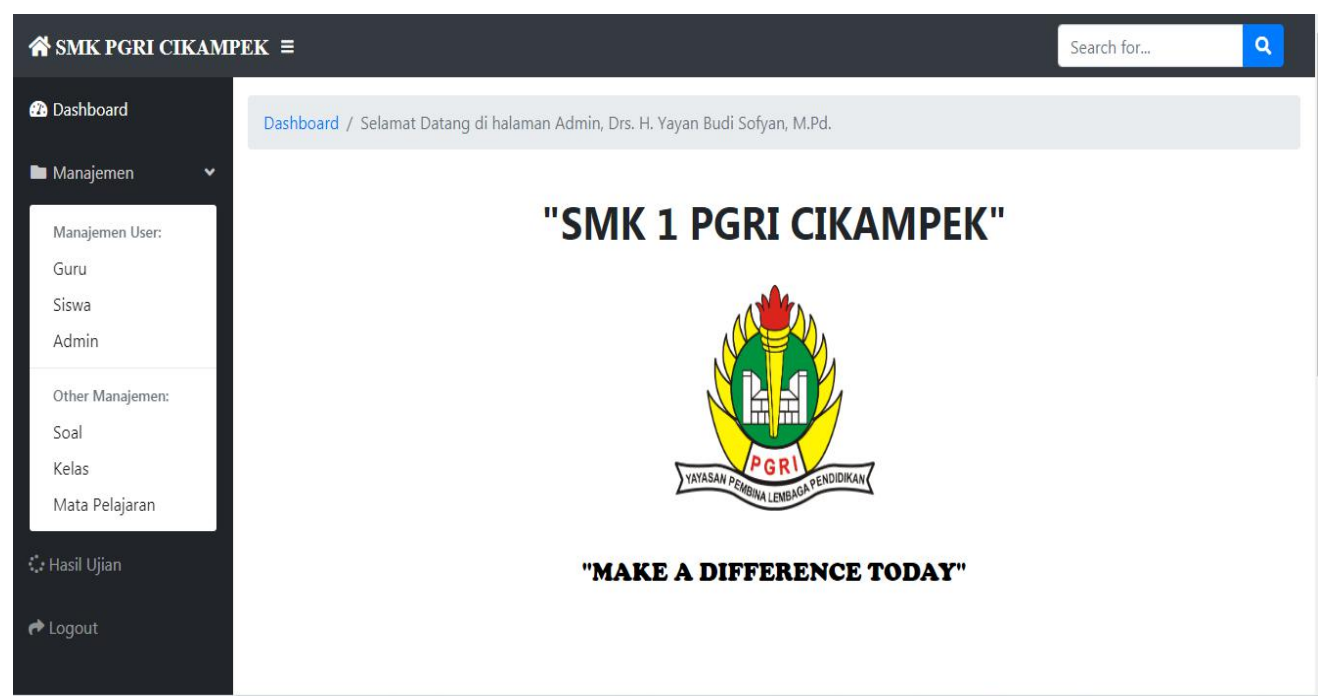

Gmbar 4.1: Halaman Menu Utama Sistem Ujian online berbasis website

Sebelum mengakses ke halaman ujian atau pengelolaan data admin user diarahkan ke menu awal untuk dapat memilih beberapa fungsi, halaman awal terbagi atas dua fungsi yaitu admin dan pengguna biasa diantaranya guru dan siswa/i. Setiap pengguna memiliki hak akses yang berbeda dalam melakukan aktifitas pada sistem informasi ujian online berbasis website ini.

\section{Tampilan pengguna Guru}

Pada halaman pengguna Guru, user dapat melihat hasil ujian yang di ujikan secara online.

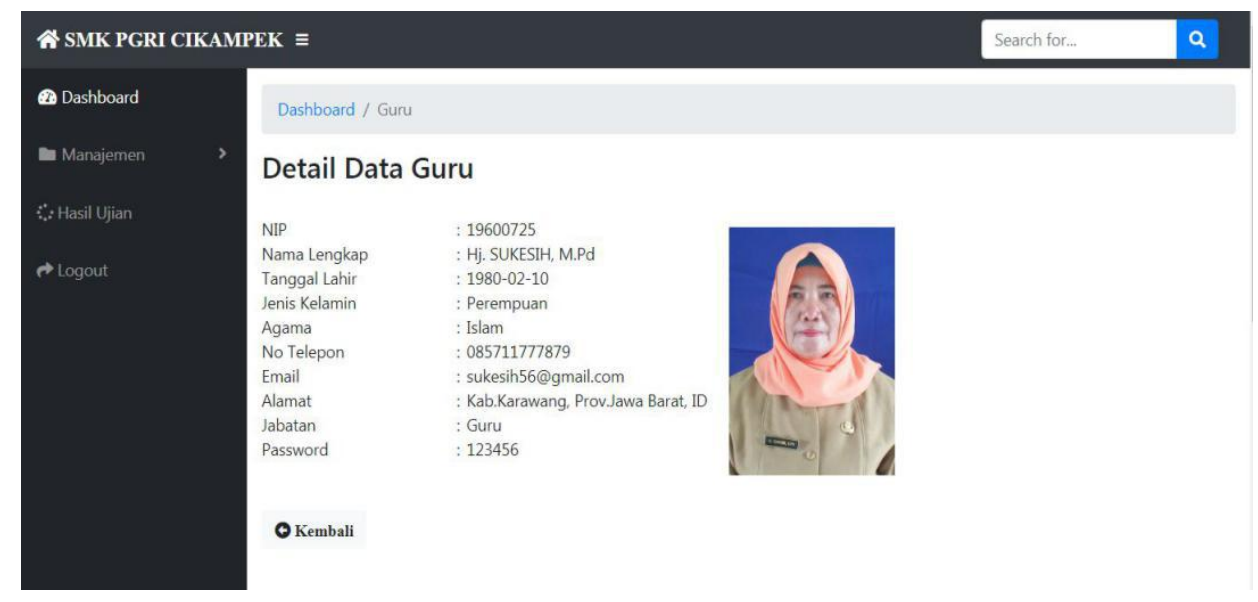

Gmbar 4.2: Halaman Guru 


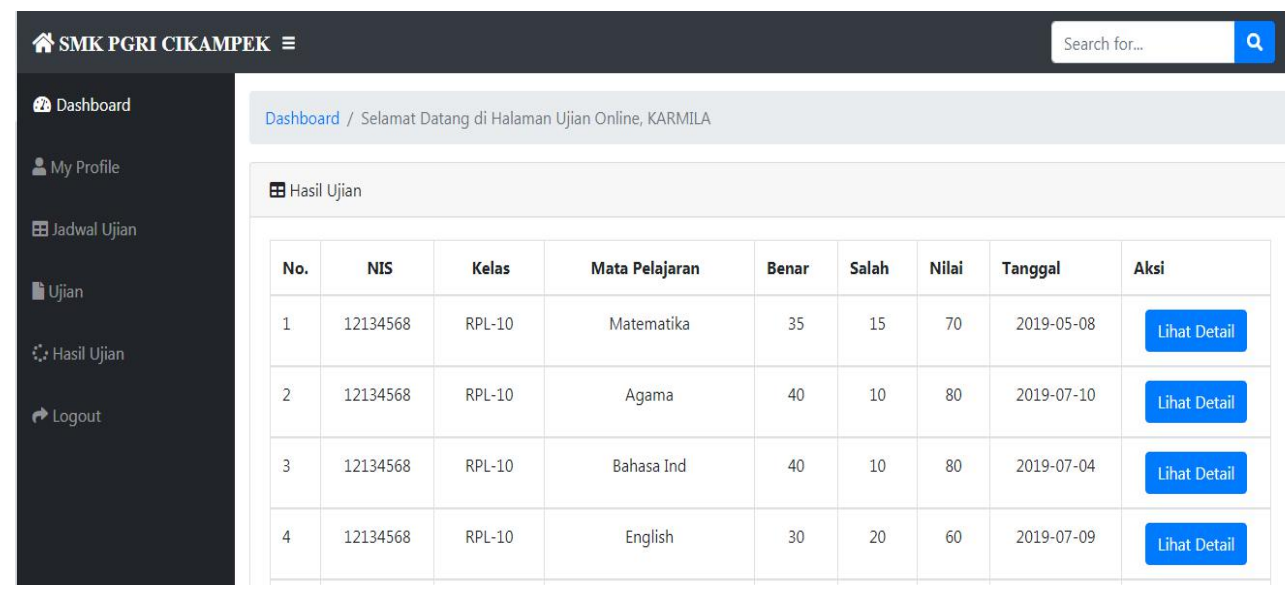

Gambar 4.3: Tampilan halaman hasil ujian siswa

\section{Tampilan Menu Siswa}

Pada halaman pengguna siswa, siswa dapat melihat daftar mata pelajaran yang akan diujikan secara online dan juga dapat mengerjakan soal-soal dari setiap mata pelajaran yang dipilih sesuai dengan jadwal. Berikut adalah gambar dari halaman menu siswa.

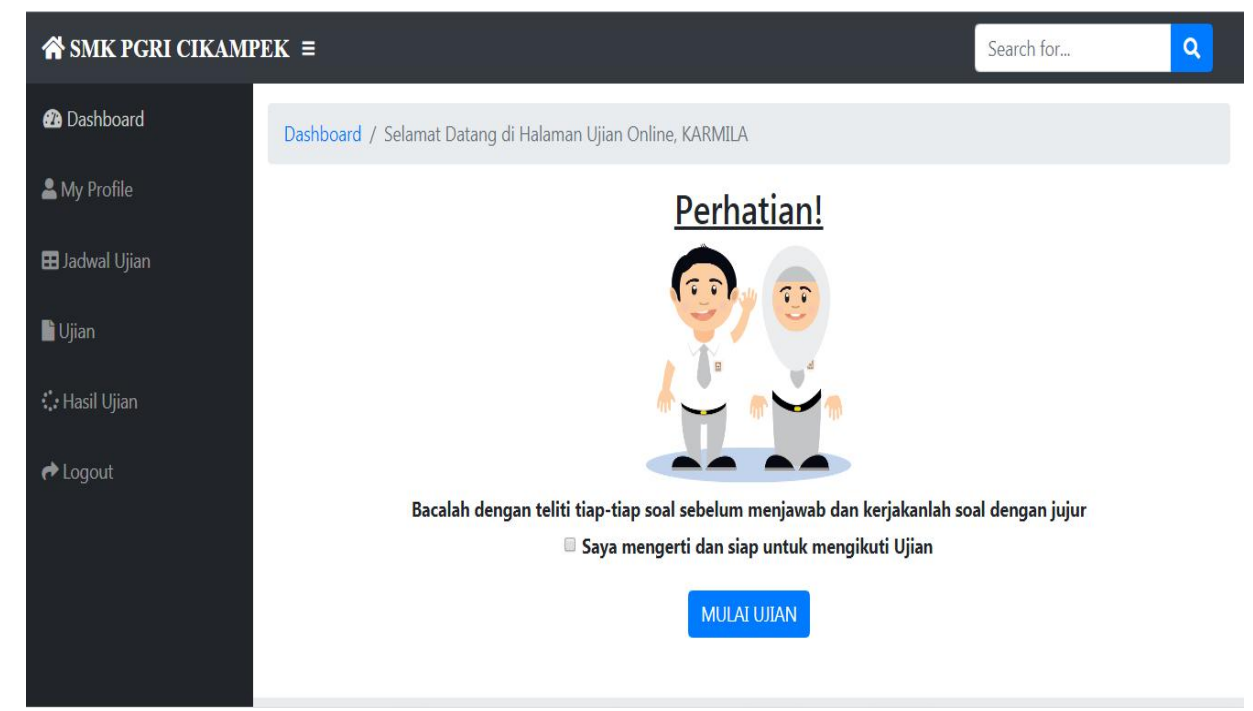

Gambar 4.4: Tampilan menu halaman siswa

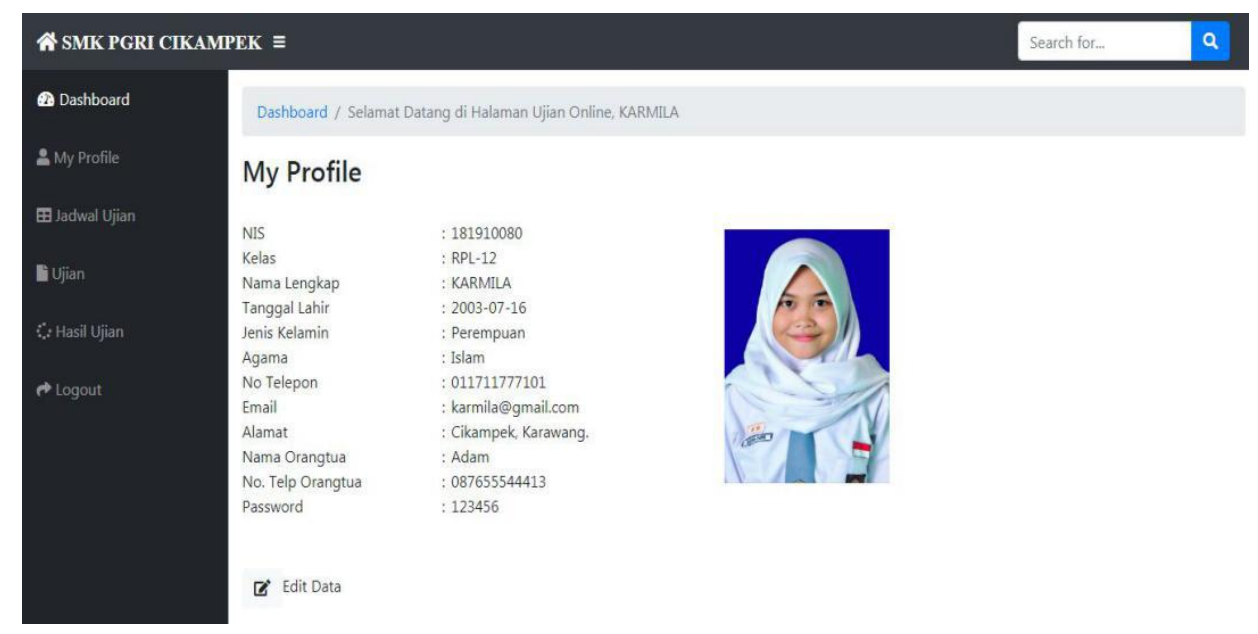


Gambar 4.5: Tampilan halaman profil siswa

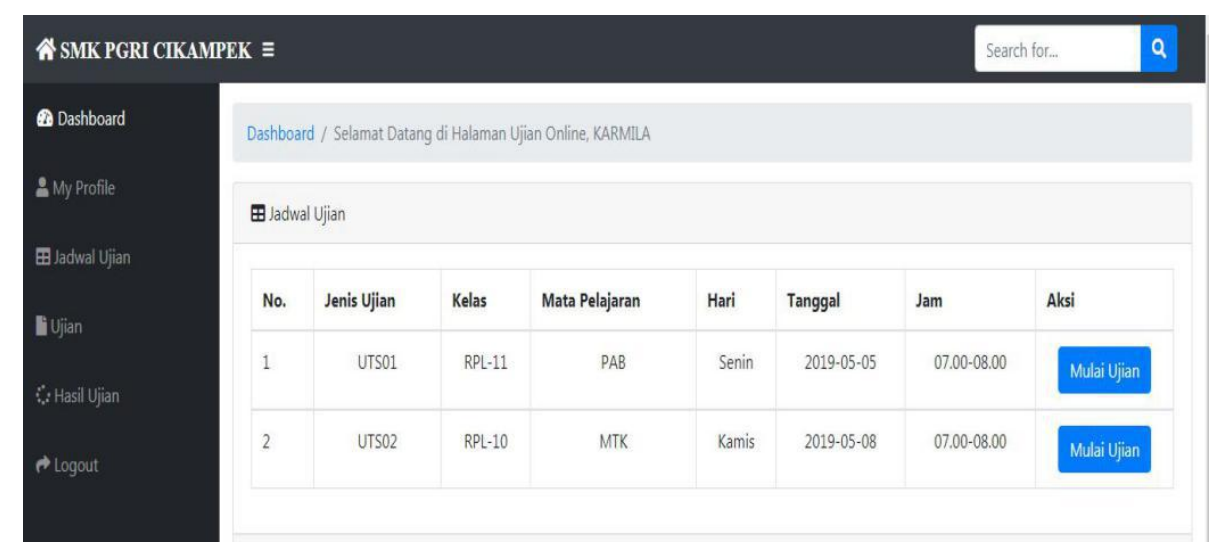

Gambar 4.6: Tampilan jadwal ujian

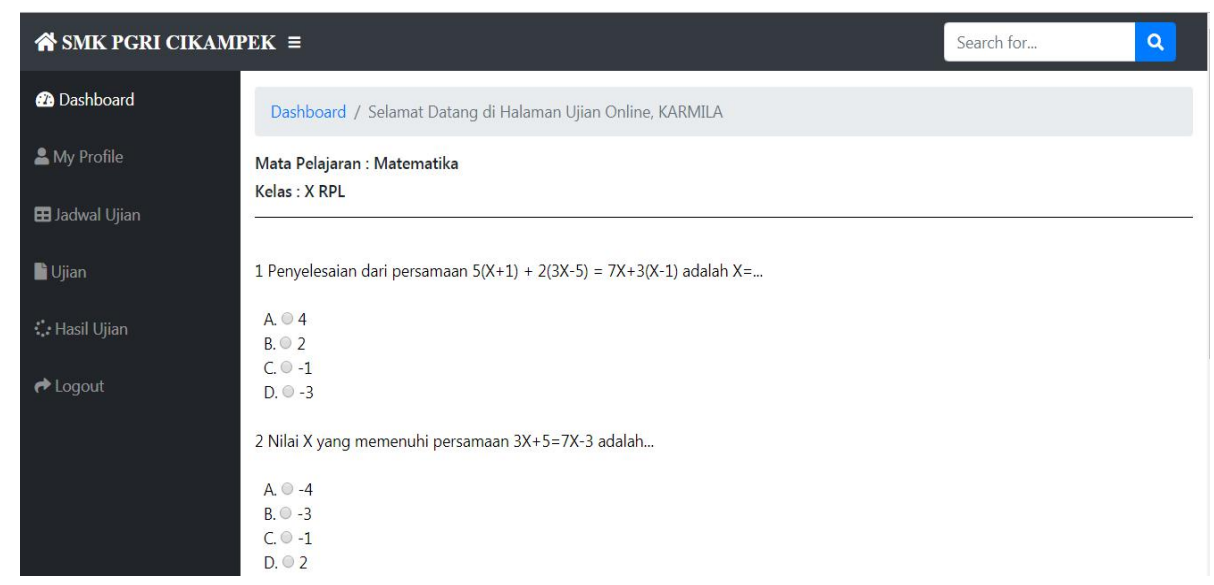

Gambar 4.7 : Tampilan halaman siswa menu Ujian

\section{B. Pengujian Unit}

Black-Box Testing merupakan Teknik pengujian perangkat lunak yang berfokus pada spesifikasi fungsional dari perangkat lunak[12]. Pengujian unit atau blackbox testing digunakan untuk mengukur kinerja sistem yang sudah di implementasikan, adapun hasil

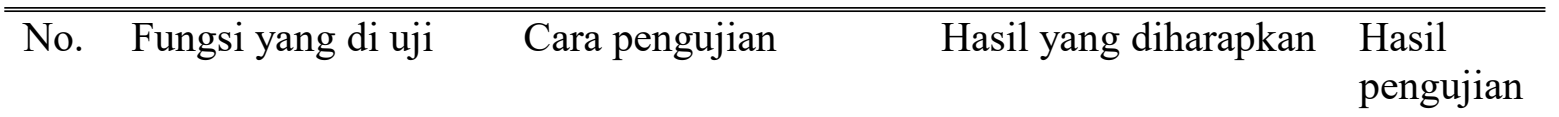

\begin{tabular}{llllrl}
\hline \hline Halaman login & pada halaman login & guru, siswa dan admin & OK \\
& terdapat & beberapa & dapat masuk ke dalam & \\
& jenis & pengguna & sistem & dengan & \\
& diantaranya: & admin, & memasukan & \\
& guru dan & siswa. & username: & NIK(guru & \\
& Pengguna memasukan & dan & admin) \\
& username: NIK(guru & siswa(NIS) & dan \\
& dan & admin) & password & \\
& siswa(NIS) & dan & & \\
& password & & & \\
& & & & \\
& &
\end{tabular}

dari tes uji sistem dengan menggunakan blackbox testing sebagai berikut: 


\begin{tabular}{|c|c|c|c|c|}
\hline 2 & Halaman guru & $\begin{array}{l}\text { Guru masuk } \\
\text { halaman hasil ujian } \\
\text { dan memilih data } \\
\text { kelas melihat data } \\
\text { kelas lalu kemudian } \\
\text { mengecek data hasil } \\
\text { ujian siswa per kelas }\end{array}$ & $\begin{array}{l}\text { Guru dapat melihat } \\
\text { hasil ujian siswa per } \\
\text { kelas }\end{array}$ & $\overline{\mathrm{OK}}$ \\
\hline 3 & Halaman admin & $\begin{array}{l}\text { Admin login sebagai } \\
\text { pengelola sistem dan } \\
\text { melakukan update } \\
\text { data siswa, guru, } \\
\text { jadwal dan data soal } \\
\text { ujian }\end{array}$ & $\begin{array}{l}\text { Admin dapat login } \\
\text { dan mengelola data } \\
\text { siswa, guru, jadwal } \\
\text { dan soal ujian secara } \\
\text { berkala }\end{array}$ & OK \\
\hline 4 & "Halaman Siswa & $\begin{array}{lr}\text { Siswa } & \text { melakukan } \\
\text { login } & \text { dengan } \\
\text { username NIS dan } \\
\text { Password } \\
\text { tanggal/bulan/tahun. } \\
\text { Melihat jadwal ujian } \\
\text { pada menu jadwal dan } \\
\text { memilih } \\
\text { pelajaran mata } \\
\text { melakukan } \\
\text { secara online }\end{array}$ & $\begin{array}{l}\text { Siswa dapat melihat } \\
\text { jadwal ujian, } \\
\text { mengerjakan ujian } \\
\text { secara online dan } \\
\text { melihat hasil ujian }\end{array}$ & $\overline{\mathrm{OKK}}$ \\
\hline 5 & Halaman Ujian & $\begin{array}{lr}\text { Siswa melakukan } \\
\text { ujian online } & \text { sesuai } \\
\text { jadwal yang sudah } \\
\text { diberikan dengan } \\
\text { batas waktu } 60 \text { Menit } \\
\text { per mata pelajaran }\end{array}$ & $\begin{array}{ll}\text { Siswa } & \text { dapat } \\
\text { mengerjakan } & \text { ujian } \\
\text { online dengan } & \text { batas } \\
\text { waktu } 60 \text { Menit } & \end{array}$ & $\mathrm{OK}$ \\
\hline 6 & $\begin{array}{l}\text { Halaman } \\
\text { Ujian }\end{array}$ & $\begin{array}{l}\text { Siswa memilih } \\
\text { halaman jadwal dan } \\
\text { melihat jadwal ujian } \\
\text { per mata pelajaran }\end{array}$ & $\begin{array}{l}\text { Siswa dapat melihat } \\
\text { jadwal ujian secara } \\
\text { online }\end{array}$ & $\mathrm{OK}$ \\
\hline 7 & Halaman Bank Soal & $\begin{array}{l}\text { Admin melakukan } \\
\text { login dan memilih } \\
\text { menu bank soal untuk } \\
\text { menambahkan data } \\
\text { soal ujian dan kunci } \\
\text { jawaban }\end{array}$ & $\begin{array}{l}\text { Admin dapat } \\
\text { mengubah, menambah } \\
\text { dan menghapus data } \\
\text { soal ujian melalui } \\
\text { bank soal }\end{array}$ & $\mathrm{OK}$ \\
\hline
\end{tabular}




\section{SIMPULAN}

Penulis menyimpulkan bahwa dari semua pembahasan secara singkat mengenai penerapan sistem Ujian Online diantaranya sebagai berikut:

1. Era Pendidikan 4.0 sangat berpengaruh bagi dunia pendidikan, seperti turut mengalami peningkatan dalam hal kualitas, kecepatan dan kepraktisan. Ujian online dapat dikatakan termasuk kedalam era Pendidikan 4.0 karena ujian konvensional (manual) telah bergeser ke arah komputerisasi.

2. Saat ini belum banyak sekolah di daerah cikampek yang menyelenggarakan UTS dan UKK secara online. Dengan ujian online sekolah dapat meminimalisir masalah-masalah yang terjadi pada pelaksanaan ujian konvensional (manual) karena dengan sistem komputer semua dapat dikelola dan dipantau lebih rapih secara mudah dan terpusat.

3. Pada system ujian online untuk memimalisir kecurangan mencontek antar siswa dapat menggunakan fungsi random soal, karena soal yang disajikan bervariasi sehingga soal yang ditampilkan akan berbeda-beda antara siswa peserta ujian.

4. Untuk membangun system ujian online berbasis web ini diperlukan aplikasi editor seperti Adobe Dreamweaver atau Sublime Text, dan Web server seperti MySQL, Oracle dll.

\section{UCAPAN TERIMAKASIH}

Dengan berakhirnya penelitian yang dilakukan penulis, bahwa hasil penelitian ini tidak akan terlaksana tanpa adanya pihak-pihak yang memberikan dukungan. Penulis ingin menyampaikan terima kasih yang sebesar-besarnya kepada Pihak sekolah SMK 1 PGRI Cikampek khususnya kepada Bapak Drs. H. Yayan Budi Sofyan, M.Pd selaku Kepala Sekolah SMK PGRI Cikampek dan Bapak Irbab Mukhorobin, S.T selaku Wakil Kepala Sekolah Kurikulum SMK PGRI Cikampek beserta staff jajarannya.

\section{DAFTAR PUSTAKA}

[1] D. Rahmawanto, E., \& Soyusiawaty, "SISTEM INFORMASI UJIAN MANDIRI ONLINE BERBASIS WEB,” J. Sarj. Tek. Inform., vol. 3, no. 1, pp. 80-88, 2015.

[2] Y. Mulyati, Konsep Sistem Informasi, vol. 3, no. 1. Yogyakarta: Deepublish, 2005.

[3] D. F. Saefudin, "Analisa Dan Perancangan Aplikasi Persediaan Obat Studi Kasus: Klinik Umum," Paradig. - J. Komput. dan Inform., vol. 20, no. 1, pp. 96-100, 2018.

[4] U. Ramadhan, S. F., \& Rusmawan, Membangun Aplikasi dengan PHP, Codeigniter, dan Ajax. Jakarta: PT Elex Media Komputindo, 2018.

[5] N. Rohman, F., Hasta Yanto, A. B., \& Sutarsih, "RANCANG BANGUN SISTEM INFORMASI UJIAN ONLINE BERBASIS WEB MENGGUNAKAN METODE WATERFALL (Studi Kasus : SMK Darma Nusantara Pandeglang)," Indones. J. Netw. Secur., vol. 7, no. 3, pp. 22-27, 2018.

[6] D. D. Saraswati, N. S., \& Utami Putra, "SISTEM UJIAN ONLINE BERBASIS WEBSITE,”J.S@CIES, vol.6, no. 1,pp.21-29, 2015.

[7] M. C. Mubarok, A., \& Kurniawan, "APLIKASI UJIAN ONLINE PADA SMK MA'ARIF BANDUNG BERBASIS WEB," Informatika, vol. II, no. 1, pp. 332-334, 2015.

[8] T. Susilowati, S., \& Hidayat, "RANCANG BANGUN SISTEM INFORMASI 
UJIAN ONLINE (Studi Kasus Pada SMAN 58 Jakarta)," J. Tek. Komput., vol. 4, no. 1, pp. 30-36, 2018.

[9] W. W. Widiyanto, "MENGGUNAKAN WATERFALL DEVELOPMENT MODEL ," J. Inf. Politek. Indonusa Surakarta, vol. 4, 2018.

[10] M. A. S, Rosa \& Shalahuddin, Rekayasa Perangkat Lunak Terstruktur dan Berorientasi Objek Edisi Revisi. Bandung: INFORMATIKA, 2018.

[11] D. Puspitasari, "SISTEM INFORMASI PERPUSTAKAAN SEKOLAH BERBASIS WEB,” J. Pilar Nusa Mandiri, vol. XII, no. 2, p. 227, 2016.

[12] T. S. Jaya, "Pengujian Aplikasi dengan Metode Blackbox Testing Boundary Value Analysis (Studi Kasus: Kantor Digital Politeknik Negeri Lampung)," J. Inform. Pengemb. IT, vol. 3, no. 2, pp. 45-46, 2018.

[13] O. C. Suibto et al., "Perancangan Sistem Informasi Booking Perekaman E-Ktp (Si Mbok) Berbasis Web," Paradig. - J. Komput. dan Inform., vol. 2, no. 2, pp. 96-100, 2019.

[14] U. Ramadhan, S. F., \& Rusmawan, Membangun Aplikasi dengan PHP, Codeigniter, dan Ajax, vol. 3, no. 1. 2015.

[15] E. Fitriani et al., "IMPLEMENTASI MODEL WATERFALL PADA SISTEM INFORMASI AKADEMIK BERBASIS WEB PADA SMK PERTANIAN KARAWANG," vol. 15, no. 2, pp. 137-144, 2018. 